\title{
Smartphone and Facebook addictions share common risk and prognostic factors in a sample of undergraduate students
}

\author{
Dependência de smartphone e dependência de Facebook compartilham fatores \\ de risco e prognósticos em uma amostra de estudantes universitários
}

\author{
Julia Machado Khoury,,$^{1,2}$ (D) Maila de Castro Lourenço das Neves, ${ }^{1,3}$ Marco Antônio Valente Roque, ${ }^{3}$ \\ André Augusto Correa de Freitas, ${ }^{3}$ Michele Ralil da Costa, ${ }^{3}$ Frederico Duarte Garcia ${ }^{1,2,3,4}$
}

\begin{abstract}
Introduction: To improve the comprehension of the interface between smartphone addiction (SA) and Facebook addiction (FA), we hypothesize that the occurrence of both technological addictions correlate, with higher levels of negative consequences. Moreover, we hypothesize that SA is associated with lower levels of social support satisfaction.

Methods: We recruited a convenience sample of undergraduate students from Universidade Federal de Minas Gerais, with age ranging between 18 and 35 years. All subjects completed a selffulfilled questionnaire comprising sociodemographic data, the Brazilian Smartphone Addiction Inventory (SPAI-BR), the Bergen Scale for Facebook Addiction, the Barrat Impulsivity Scale 11 (BIS-11), the Social Support Satisfaction Scale (SSSS), and the Brief Sensation Seeking Scale (BSSS-8). After completing the questionnaire, the interviewer conducted a Mini-International Neuropsychiatric Interview (MINI).

Results: In the univariate analysis, SA associated with female gender, with ages 18 to 25 years, FA, substance abuse disorders, major depressive disorder, anxiety disorders, low scores in SSSS, high scores in BSSS-8, and high scores in BIS. The group with SA and FA presented a higher prevalence of substance abuse disorders, depression, and anxiety disorders when compared to the group with SA only.

Conclusion: In our sample, co-occurrence of SA and FA correlated with higher levels of negative consequences and lower levels of social support satisfaction. These results strongly suggest that SA and FA share some elements of vulnerability. Further studies are warranted to clarify the directions of these associations.

Keywords: Smartphone addiction, Facebook addiction, social network addiction, social support, sensation seeking, impulsivity.
\end{abstract}

\section{Resumo}

Introdução: Para melhorar a compreensão da interface entre dependência de smartphone (DS) e a dependência de Facebook (DF), avaliamos a hipótese de que a ocorrência simultânea de ambas as dependências corelaciona-se com o número de consequências negativas por elas produzidas. Além disso, avaliamos se a DS está associada a níveis mais baixos de satisfação com o suporte social.

Método: Recrutamos uma amostra de conveniência de estudantes de graduação da Universidade Federal de Minas Gerais, na faixa de 18 e 35 anos. Todos os sujeitos preencheram o questionário avaliando dados sociodemográficos e contendo a versão brasileira do Smartphone Addiction Inventory, a Escala de Bergen para DF, a Escala de Impulsividade de Barrat 11 (BIS-11), a Escala de Satisfação com o Suporte Social (SSSS) e a Escala Breve de Busca de Sensações (BSSS-8). Após o preenchimento do questionário, os entrevistadores realizaram a Mini-International Neuropsychiatric Interview.

Resultados: $\mathrm{Na}$ análise univariada, a DS associou-se ao sexo feminino, pessoas na faixa de idade entre 18 e 25 anos, rastreio para $\mathrm{DF}$, transtornos por uso de substâncias, transtorno depressivo maior, transtornos de ansiedade, baixos escores na SSSS, altos escores na BSSS-8 e altos escores na BIS. O grupo rastreado positivamente para DS e DF apresentou maior prevalência de transtornos por uso de substâncias, depressão e transtornos de ansiedade quando comparado ao grupo rastreado apenas para DS.

Conclusão: Na amostra avaliada, a comorbidade de DS e DF se correlacionou a níveis mais altos de consequências negativas e níveis mais baixos de satisfação com o suporte social. Esses resultados sugerem que DS e DF compartilham fatores de vulnerabilidade. Estudos adicionais são necessários para esclarecer a direção dessas associações.

Descritores: Dependência de smartphone, dependência de Facebook, dependência de redes sociais, suporte social, busca por sensações, impulsividade.

\footnotetext{
${ }^{1}$ Departamento de Saúde Mental, Universidade Federal de Minas Gerais (UFMG), Belo Horizonte, MG, Brazil. 2 Programa de Pós-Graduação em Medicina Molecular, Faculdade de Medicina, UFMG, Belo Horizonte, MG, Brazil. ${ }^{3}$ Núcleo de Pesquisa em Vulnerabilidade a Saúde (NAVES), UFMG, Belo Horizonte, MG, Brazil. ${ }^{4}$ Unité Inserm U1073, Rouen, France.

Submitted Aug 08 2018, accepted for publication Mar 082019.

Suggested citation: Khoury JM, Neves MCL, Roque MAV, Freitas AAC, da Costa MR, Garcia FD. Smartphone and Facebook addictions share common risk and prognostic factors in a sample of undergraduate students. Trends Psychiatry Psychother. 2019;41(4):358-368. http://dx.doi.org/10.1590/2237-6089-2018-0069
} 


\section{Introduction}

Smartphone technologies are central for today's wellbeing. They provide portability, real-time connection, and a broad range of solutions that have transformed their use into an everyday need. ${ }^{1-3}$ Smartphone users are exposed, on average, to 2.5 hours of screen time per day, according to a recent study. ${ }^{4}$ Despite the significant benefits that may be provided by smartphones, several researchers alert to the potential adverse effects of abusing their use.

A growing body of evidence strongly suggests that some subjects develop a compulsion related to smartphone use that results in adverse outcomes. Among those outcomes we find: a decrease in academic and work performance; the impairment of interpersonal relationships; an increased prevalence of traffic accidents; and sleep disorders. ${ }^{5-10}$ More recently, in a study using self-report data assessing private, workplace-related smartphone use, and selfrated productivity, Duke \& Montag reported a moderate association between smartphone addiction and a selfreported decrease in productivity due to spending time on the smartphone at the workplace. ${ }^{11}$

In the last decade, several studies reinforced the hypothesis that this compulsion may be considered a behavioral addiction by assessing profiles of subjects at risk to develop a compulsive use of smartphones. The factors already associated with addictive behavior are grouped in 1) demographics (i.e., accessibility to mobile phones, female sex, ${ }^{12-16}$ age ranging from 18 to 25 years old, ${ }^{5,17-19}$ medium and high family income $6,12,20,21)$; 2) personality traits (i.e., impulsivity, ${ }^{22-}$ 26 sensation seeking, ${ }^{22-26}$ low self-directedness, ${ }^{27}$ low willpower, ${ }^{27}$ high neuroticism, ${ }^{27}$ low agreeableness, ${ }^{27}$ low conscientiousness, ${ }^{27}$ and extroversion ${ }^{28}$ ); and 3 ) comorbidities (i.e., mental disorders ${ }^{29-35}$ and substance abuse disorders ${ }^{17,25,36,37}$ ).

As evidence regarding technological addiction grows, nosological classifications recognize some patterns of excessive use of technology as pathological. Recently, the Diagnostic and Statistical Manual of Mental Disorders, 5th edition (DSM-5) included Internet gaming disorder in Section III, ${ }^{38}$ and the International Classification of Diseases (ICD) included gaming disorder as a specific diagnostic category. ${ }^{8}$ Despite the growing evidence demonstrating the existence of compulsive use of smartphones, the inclusion of this disorder in an official nosologic classification has not yet occurred. ${ }^{39,40}$ Due to the lack of a consensual definition, a clear pattern of symptoms, and a diagnostic category, several terms have emerged to describe the pathological use of smartphones. Some authors have named this behavior as problematic smartphone use, ${ }^{27}$ smartphone use disorder, ${ }^{41}$ or smartphone addiction (SA). ${ }^{25}$

The addictive disorder is not related to the smartphone itself, but rather to the applications and functions provided by it. Some authors formulated hypotheses to explain the cognitive mechanisms underpinning smartphone use disorder. The dual system theory, proposed by Soror et al., ${ }^{42}$ suggests that a conflict between the reflexive/automatic system (e.g., responding to a message when we hear our phone ring) and the reflective/control system (monitoring if the situation is appropriate, i.e., not answering the phone while driving) influences mobile phone use and may explain the negative consequences associated with their use. ${ }^{43}$ Another theoretical framework, proposed by Billieux et al., associates three pathways to mobile phone use. ${ }^{44}$ The first is the excessive reassurance pathway, where subjects present high anxiety, low self-esteem experience and a need for reassurance that is met with the excessive use of smartphones. The second is the impulsive pathway, corresponding to low self-control that can result in excessive use of the smartphone, accompanied by symptoms of addiction, an antisocial pattern of smartphone use and/or risky mobile phone use behavior. Third, there is the extraversion pathway, i.e., when the addictive outcomes are expressed in subjects who have the constant need to socialize with others.

Moreover, Elhai et al. ${ }^{45}$ have proposed that mood changes resulting from smartphone use act as positive reinforcement in seeking excessive reassurance or the unwillingness to miss relevant information, corresponding to negative reinforcement in the smartphone use habituation process. ${ }^{46}$

Because the source of the compulsive behavior is not the smartphone itself, but rather the Internet content accessed through it, it is essential to focus on social media applications in order to better understand the smartphone abuse behavior. Social networks, especially WhatsApp ${ }^{\circledR}$ and Facebook ${ }^{\circledR}$, are predominantly used through smartphones. ${ }^{16,47,48}$ The accessibility and portability of these devices improve access to the Internet, favoring the abuse of and dependency on social networks. In a study by Montag et al., in a large sample assessed for a period of four weeks, WhatsApp ${ }^{\circledR}$ accounted for near $20 \%$ of all smartphone use. ${ }^{28}$ In this regard, some authors have been studying the overlap of SA with social network addiction, in particular Facebook addiction (FA). 25,37,49-55

The estimated prevalence of FA ranges from 1.6 to $41.8 \%{ }^{56}$ of users. Facebook dependents tend to have a lower self-esteem and lower levels of life satisfaction, using Facebook as a way to regulate their emotions ${ }^{57}$ 
when compared to healthy social network users. ${ }^{58}$ Montag et al. reported that extroversion and low conscientiousness are associated with social network addiction through the smartphone. ${ }^{28}$

Low social support satisfaction may be one of the main factors associated with dependence on social networks through smartphones. Lachmann et al. ${ }^{41}$ assessed alterations of social support satisfaction in individuals with problematic Internet use and problematic smartphone use. The authors measured empathy and life satisfaction and reported that problematic Internet use and problematic smartphone use associated with both lower empathy and lower life satisfaction scores. The authors reported that, in the sample assessed, the subjects used social networks with the goal of achieving approval and social support. ${ }^{16,48}$

To improve the comprehension of the interface between SA and FA, we hypothesize that there is a correlation between both technological addictions and higher levels of negative consequences in subjects with both addictions. Moreover, we hypothesize that SA also associates with a lower level social support satisfaction. To assess these hypotheses, we compared the consequences of SA in the social support of subjects presenting both SA and FA vs. those presenting SA only, using a sample of undergraduate students.

\section{Methods}

\section{Participants}

We performed a cross-sectional observational study that assessed a convenience sample of undergraduate students from Universidade Federal de Minas Gerais (UFMG). Previously trained interviewers approached potential participants at points of student congregation in the campus area (i.e., restaurants, libraries, bus stops).

We included subjects aged between 18 to 35 years who owned a smartphone with Internet access and who were able to provide written consent. We excluded subjects presenting severe visual and/or hearing impairment, or who were unable to provide informed consent. Data collection occurred from March 2016 to July 2016.

The inclusion and exclusion criteria used in this study considered the most prominent risk profile for SA, according to previous studies. ${ }^{59-67}$

\section{Measures}

To assess SA likelihood, we used the Brazilian version of the Smartphone Addiction Inventory (SPAI-BR). The SPAI-BR is an SA screening scale comprising 26 dichotomous items validated for use with undergraduate students. The cutoff point of 7 positive questions presented good reliability and validity in this population, as previously determined by our research group. ${ }^{68}$ The Brazilian version ${ }^{69}$ of the Bergen Scale for Facebook Addiction ${ }^{70}$ was used to assess FA in participants. Subjects who scored 4 or 5 in at least 4 of the items were considered positive for FA. To assess comorbid psychiatric disorders, we used the subscales of the Brazilian version of the Mini-International Neuropsychiatric Interview (MINI), ${ }^{71,72}$ focusing on 1) generalized anxiety disorder (GAD); 2) alcohol, cannabis, and stimulant use disorders; 3 ) social phobia; and 4) obsessive-compulsive disorder.

To assess social support perception, we used the Brazilian version of the Social Support Satisfaction Scale (SSSS), which comprises 15 Likert-type questions and was developed and validated by Ribeiro to assess social support in its four dimensions: 1) satisfaction with friends; 2) intimacy; 3) satisfaction with family; and 4) social activities. Instrument scores range from 15 to 75 points, with higher scores indicating increased levels of social support. ${ }^{73}$

The Barrat Impulsivity Scale 11 (BIS-11) was used to assess global impulsivity, ${ }^{74}$ with higher scores indicating higher levels of impulsivity. We used the global score as a measure of dysfunctional impulsivity, shown in previous studies to be suitable for use in the Brazilian population. 74,75

Finally, we used the Brazilian version of the Brief Sensation Seeking Scale (BSSS-8), ${ }^{76,77}$ to assess personality traits related to SA and FA. The BSSS- 8 is an 8-item Likert-type scale divided in four subscales: 1 ) looking for excitement and adventure; 2) disinhibition; 3) search for experience; and 4) susceptibility to boredom. ${ }^{78}$ Scores range from 8 to 40 , with higher scores indicating an increased tendency for sensation seeking.

\section{Procedures}

After signing the informed consent, the interviewers requested subjects to perform a paper-and-pencil questionnaire assessing demographic information (i.e., biological gender, race, date of birth, marital status, and family income), the SPAI-BR, the Bergen Scale, the BIS-11, the SSSS, and the BSSS-8. After completion of the questionnaires, the interviewers conducted a MINI structured interview.

\section{Statistical analysis}

In descriptive analysis, we calculated mean, standard deviation (SD), median, quartiles, and range for continuous variables; and absolute, relative frequencies, 
and proportions for categorical variables. We assessed data normality using the Kolmogorov-Smirnov test; all the continuous variables assessed presented a non-normal distribution. Furthermore, we used the chi-square test to compare categorical variables and the Mann-Whitney test to compare continuous variables. We dichotomized the age variable into two groups: $18-25$ and $26-35$ years of age. This dichotomization was adopted in accordance to the an equivalent strategy used by some authors who reported that subjects between 18 and 25 years of age are more prone to develop SA..$^{5,17-19}$ Monthly household income was categorized according to criteria from the Brazilian Institute of Geography and Statistics, as follows: low ( $\leq$ US\$ 794), average (US\$ 794 to 3,969), and high ( $\geq$ US $\$ 3,970$ ). To calculate the odds ratio (OR) of the factors associated with positive screening for $\mathrm{SA}$, we conducted multiple logistic regression with a stepwise backward selection. Variables with $p \leq 0.2$ in the univariate analysis were considered appropriate to enter the model. Statistical analyses were considered significant when $\mathrm{p}<0.05$. All analyses were performed using the Statistical Package for the Social Sciences (SPSS) version 20.

\section{Ethics}

The study procedures were carried out according to the latest version of the Declaration of Helsinki, with the approval of the institutional review board of the UFMG. All subjects were informed of the study scope and objectives and provided written informed consent.

\section{Results}

\section{Sample description}

At endpoint, 415 students were included in the study, with a mean age \pm SD of $23.6 \pm 3.4$ years; $77.3 \%$ were in the 18-25-year old age group. Women accounted for $54.5 \%$ of the participants, and no statistical difference was found between the number of individuals of both genders $(p=0.42)$. The prevalence of SA was $43.85 \%$ $(n=182)$, and of FA, $13 \%(n=54)$ (Table 1$)$.

\section{Univariate analysis}

In the univariate analysis, the female gender $\left(\mathrm{X}^{2}{ }_{1}=\right.$ $11.2522, p<0.001)$ and age between 18 to 25 years $\left(X^{2}{ }_{1}=5.8389, p=0.016\right)$ were significantly associated with a positive screening for SA. We found no statistically significant association between SA and marital status $\left(\mathrm{X}^{2}{ }_{1}=2.0985, \mathrm{p}=0.147\right)$, self-reported race/skin color $\left(X^{2}{ }_{1}=1.742, p=0.187\right)$ or monthly household income $\left(X_{2}^{2}=2.2975, p=0.317\right)$ (Table 2$)$.
Being diagnosed with FA $\left(X^{2}{ }_{1}=5.0154, p=0.025\right)$, substance abuse disorder $\left(X^{2}=22.5022, p<0.001\right)$, major depressive disorder $\left(X^{2}=32.9139, p<0.001\right)$, and anxiety disorder $\left(X^{2}{ }_{1}=68.7723, p<0.001\right)$ was strongly correlated with a positive screening for SA in the univariate analysis.

Finally, low scores in the SSSS $(z=5.681, p<0.001)$, high scores in the BSSS- $8(z=-2.331, p<0.001)$, and high scores in the BIS-11 $(z=-5.732, p<0.001)$ were strongly associated with a positive screening for SA (Table 2). Analysis of the variable monthly household income was performed considering only 375 individuals, because 40 individuals did not answer this question. Of the 375 individuals who reported their income, 133 $(35.5 \%)$ were dependent on smartphones, and 242 (64.5\%) were not dependent on smartphones. Analysis of the variable FA was performed considering a total of 246 individuals who reported having Facebook, of which 169 presented SA and the remaining 77 did not.

\section{Multivariate analysis}

The multivariate analysis showed a proper fit of the model according to the Hosmer-Lemeshow goodness of fit test $(p=0.3796)$. The Nagelkerke coefficient of determination explained $34 \%$ of the model $\left(R^{2}=\right.$ 0.3412 ). The results of the multivariate analysis are presented in Table 3.

Table 1 - Sociodemographic characteristics of study participants

\begin{tabular}{|c|c|c|}
\hline Characteristics & $\mathbf{n}$ & $\%$ \\
\hline \multicolumn{3}{|l|}{ Gender } \\
\hline Female & 226 & 54.5 \\
\hline Male & 189 & 45.5 \\
\hline \multicolumn{3}{|l|}{ Age in years } \\
\hline $18-25$ & 321 & 77.3 \\
\hline $26-35$ & 94 & 22.7 \\
\hline \multicolumn{3}{|l|}{ Marital status } \\
\hline Married & 21 & 5.1 \\
\hline Unmarried & 394 & 94.9 \\
\hline \multicolumn{3}{|l|}{ Skin color } \\
\hline White & 252 & 60.7 \\
\hline Non-white & 145 & 35 \\
\hline Unanswered & 18 & 4.3 \\
\hline \multicolumn{3}{|l|}{ Household income } \\
\hline$<$ US\$ 794 & 72 & 17.4 \\
\hline US $\$ 794$ to 3,969 & 222 & 53.5 \\
\hline$\geq$ US\$ 3,970 & 81 & 19.6 \\
\hline Unanswered & 40 & 9.6 \\
\hline
\end{tabular}

Trends Psychiatry Psychother. 2019;41(4) - 361 


\section{Characteristics of SA subjects with and without comorbid FA}

Of the 182 individuals positively screened for SA, 169 (92.86\%) reported using Facebook; of these, 54 $(29.7 \%)$ tested positive for FA. We further subdivided the group of individuals with SA using Facebook ${ }^{\circledR}(n=169)$ into two groups: 1$)$ individuals with FA ( $n=54)$; and 2 ) individuals without FA $(n=115)$. We then compared these subgroups according to sociodemographic characteristics and psychiatric comorbidities.

The group with concomitant SA and FA presented higher prevalences of substance abuse disorders, depression, and anxiety disorders when compared to the SA only group. The group with concomitant SA and FA presented greater impulsivity and lower social support satisfaction when compared to the SA only group.
We compared the means and the medians of total SPAI-BR scores and both parameters were increased in the comorbid SA and FA group (Table 4). In Table 5 we present correlations between SPAI-BR scores and age, the Bergen Scale for Facebook Addiction, BIS-11, SSSS, and BSSS.

Regarding SPAI-BR scale scores, all variables analyzed showed significant Spearman correlation coefficients. The variables age and satisfaction with social support showed negative coefficients, i.e., as these variables increased, a reduction was observed in SPAI-BR scores. The variables Facebook addiction, impulsivity and sensation seeking showed positive coefficients, i.e., as these variables increased, an increase was observed in SPAI-BR scores.

Table 2 - Factors associated with smartphone addiction in the univariate analysis

\begin{tabular}{|c|c|c|c|c|c|c|}
\hline \multirow[b]{3}{*}{ Characteristic } & \multicolumn{4}{|c|}{ Smartphone addiction } & \multirow[b]{3}{*}{$X^{2}(d f)$} & \multirow[b]{3}{*}{$\mathbf{p}$} \\
\hline & \multicolumn{2}{|c|}{ Negative $(n=233)$} & \multicolumn{2}{|c|}{ Positive ( $n=182)$} & & \\
\hline & $\mathbf{n}$ & $\%$ & $\mathbf{n}$ & $\%$ & & \\
\hline Female gender & 110 & 47.2 & 116 & 63.74 & $11.2522(1)$ & $<0.001$ \\
\hline $18-25$ years old & 170 & 73 & 151 & 83 & $5.8389(1)$ & 0.016 \\
\hline Not married & 218 & 93.6 & 176 & 96.7 & $2.0985(1)$ & 0.147 \\
\hline White race/skin color & 148 & 63.5 & 104 & 57.14 & $1.742(1)$ & 0.187 \\
\hline \multicolumn{7}{|l|}{ Household income } \\
\hline$<$ US\$ 794 & 34 & 16.4 & 38 & 22.6 & & \\
\hline US\$ 794 to 3969 & 127 & 61.4 & 95 & 56.5 & $2.2975(2)$ & 0.317 \\
\hline Facebook addiction & 14 & 18.2 & 54 & 32 & $5.0154(1)$ & 0.025 \\
\hline Substance use disorders & 26 & 11.2 & 54 & 29.7 & $22.5022(1)$ & $<0.001$ \\
\hline Depression & 25 & 10.7 & 61 & 33.5 & $32.9139(1)$ & $<0.001$ \\
\hline \multirow[t]{2}{*}{ Anxiety disorders } & 66 & 28.3 & 126 & 69.2 & $68.7723(1)$ & $<0.001$ \\
\hline & Mean (SD) & Median (IQ) & Mean (SD) & Median (IQ) & $\mathbf{z}$ & $\mathbf{p}$ \\
\hline Satisfaction with social support & $55.52(10.4)$ & $56(15)$ & $50.24(11.6)$ & $50(16)$ & 5.681 & $<0.001$ \\
\hline Sensation seeking & $23.33(7.5)$ & $24(11)$ & $26.08(6.6)$ & $27(9)$ & -2.331 & $<0.001$ \\
\hline Impulsivity & $58(9.5)$ & $58(14)$ & $64.3(10.5)$ & $63.5(13)$ & -5.732 & $<0.001$ \\
\hline
\end{tabular}

$\mathrm{df}=$ degrees of freedom; IQ = interquartile range; $\mathrm{SD}=$ standard deviation.

Table 3 - Factors associated with smartphone addiction in multivariate analysis

\begin{tabular}{|c|c|c|c|c|c|}
\hline Characteristic & OR & $95 \% \mathrm{CI}$ & $\boldsymbol{\beta}$ & SE & $\mathbf{p}$ \\
\hline Facebook addiction & 4.44 & 2.14-9.21 & 1.491 & 1.7 & $<0.001$ \\
\hline Anxiety disorders & 4.12 & $2.10-8.91$ & 1.401 & 1.1 & $<0.001$ \\
\hline Female gender & 2.48 & $1.49-4.14$ & 0.908 & 0.6 & 0.001 \\
\hline Substance use disorders & 2.48 & $1.29-4.77$ & 0.908 & 0.8 & 0.007 \\
\hline Age between $18-25$ years old & 1.09 & 1.01-1.19 & 0.086 & 0 & 0.021 \\
\hline Impulsivity & 1.05 & $1.03-1.08$ & 0.049 & 0 & $<0.001$ \\
\hline Low satisfaction with social support & 1.03 & 1.01-1.99 & 0.03 & 0 & 0.016 \\
\hline Constant & 0.12 & $\mathrm{~N} / \mathrm{A}$ & -2.12 & 0.2 & 0.164 \\
\hline
\end{tabular}

$95 \% \mathrm{CI}=95 \%$ confidence interval for odds ratio; $\beta=$ beta coefficient; $\mathrm{N} / \mathrm{A}=$ not applicable; OR = odds ratio; SE = standard error. 
Table 4 - Comparison between subjects with smartphone addiction, with and without comorbid Facebook addiction

\begin{tabular}{|c|c|c|c|c|c|c|}
\hline & \multicolumn{4}{|c|}{ Comorbid Facebook addiction } & \multirow[b]{3}{*}{$X^{2}(d f)$} & \multirow[b]{3}{*}{$\mathbf{p}$} \\
\hline & \multicolumn{2}{|c|}{ Negative $(n=115)$} & \multicolumn{2}{|c|}{ Positive $(n=54)$} & & \\
\hline & $\mathbf{n}$ & $\%$ & $\mathbf{n}$ & $\%$ & & \\
\hline Substance use disorders & 32 & 27.83 & 19 & 35.19 & $22.53(1)$ & $<0.001$ \\
\hline Depression & 33 & 28.7 & 26 & 48.15 & $6.11(1)$ & 0.013 \\
\hline \multirow[t]{2}{*}{ Anxiety disorders } & 55 & 47.82 & 49 & 90.74 & $28.59(1)$ & $<0.001$ \\
\hline & Mean (SD) & Median (IQ) & Mean (SD) & Median (IQ) & $\mathbf{z}$ & $\mathbf{p}$ \\
\hline Satisfaction with social support & $52.9(11.5)$ & $55.0(15.0)$ & $45.6(10.1)$ & $45.4(15.0)$ & 3.1 & 0.001 \\
\hline Sensation seeking & $26.5(6.2)$ & $27.0(8.0)$ & $26.1(7.1)$ & $27.0(11.0)$ & 0.76 & 0.777 \\
\hline Impulsivity & $63.3(10.5)$ & $63.0(10.2)$ & $67.2(10.2)$ & $66.5(17.0)$ & 1.67 & 0.046 \\
\hline SPAI-BR score & $12.63(3.3)$ & $12(3)$ & $15.87(4.43)$ & $16(4)$ & -3.11 & 0.001 \\
\hline
\end{tabular}

$\mathrm{df}=$ degrees of freedom; $\mathrm{IQ}=$ interquartile range; $\mathrm{SD}=$ standard deviation; SPAI-BR = Brazilian version of the Smartphone Addiction Inventory.

Table 5 - Correlations between continuous variables

\begin{tabular}{|c|c|c|c|c|c|c|}
\hline & SPAI-BR & Age & Bergen & BIS-11 & SSSS & BSSS \\
\hline SPAI-BR & 1.000 & & & & & \\
\hline Age & $-0.136 *$ & 1.000 & & & & \\
\hline Bergen & $0.430 *$ & -0.052 & 1.000 & & & \\
\hline BIS-11 & $0.360 *$ & -0.022 & $0.170 *$ & 1.000 & & \\
\hline SSSS & $-0.261 *$ & -0.022 & $-0.377 *$ & $-0.180 *$ & 1.000 & \\
\hline BSSS & $0.220 *$ & $-0.272 *$ & 0.008 & 0.241 & -0.064 & 1.000 \\
\hline
\end{tabular}

Bergen = Bergen Scale for Facebook Addiction; BIS-11 = Barrat Impulsivity Scale 11; BSSS = Brief Sensation Seeking Scale; SPAI-BR = Brazilian version of the Smartphone Addiction Inventory; SSSS = Social Support Satisfaction Scale.

* Spearman's coefficient (Rho) significant at $p<0.05$.

\section{Discussion}

In this study, we assessed whether the concomitance of SA and FA associated with higher levels of adverse consequences, and whether SA was additionally associated with a lower level of social support satisfaction in a sample of undergraduate students. Our results strongly suggest that comorbid SA and FA present a more severe profile, characterized by higher prevalence of substance abuse disorders, depression, and anxiety disorders; lower social support satisfaction; and higher impulsivity. Therefore, when both technological addictions are present, clinical presentation is worse when compared to the isolated presence of SA.

Moreover, confirming our second hypothesis, SA was associated with lower social support satisfaction, especially when SA and FA occurred concomitantly. Therefore, we suppose that low social support satisfaction is a factor that increases vulnerability to dependence on social networks through smartphones.

In our sample, SA was strongly associated with the female gender, age between 18 and 25 years, substance abuse disorders, anxiety disorders, higher impulsivity, and lower social support satisfaction. FA was the variable most strongly associated with SA; an overlap between both disorders was found in $30 \%$ of the cases.

Although our results are compatible with our initial hypotheses, they should be regarded in light of some limitations. First, we performed a cross-sectional study, and therefore causality may not be inferred. Even as we found statistically significant differences in social support satisfaction and impulsivity between participants with comorbid SA and FA vs. SA only, the clinical significance of these differences should be regarded with care. Finally, dependence on social networks was assessed considering only Facebook, and therefore we may have excluded subjects with problems related to other social networks such as Instagram ${ }^{\circledR}$, Twitter $^{\circledR}$, Tinder $^{\circledR}$, WeChat ${ }^{\circledR}$ and WhatsApp ${ }^{\circledR}$. Despite these shortcomings, this study used a large and representative sample of undergraduate students.

The positive association found in our study between SA and some psychiatric disorders suggest the existence of a profile of vulnerability to developing SA. Previous studies have also pointed in this direction, describing an association between SA and the female gender, ${ }^{12-16,25,63,65,79-82}$ age between 18 and 
25 years, ${ }^{16-19,24,83,84}$ psychoactive substance abuse disorders, ${ }^{17,25,36,37}$ anxiety disorders, ${ }^{25,32-34,85,86}$ and high impulsivity. ${ }^{22-26}$ Smartphone abuse in individuals with these vulnerabilities could represent a way to cope with everyday stress.

In our study, subjects dependent on Facebook and smartphones concomitantly presented higher impulsivity and lower social support satisfaction. We can suppose that low impulse control induces reward searching behavior, such as the ritual of regularly checking Facebook through smartphones for hedonistic purposes. This hypothesis is compatible to Billieux's model of impulsive pathway for problematic smartphone use. ${ }^{87}$ The authors of that model propose that one of the pathways that lead to problematic smartphone use is driven by poor impulse control, resulting in uncontrollable urges and excessive use. In parallel, decreased social support satisfaction can favor Facebook abuse as a form of searching for social peers, social reinforcement and reassurance, which agrees with the excessive reassurance pathway, also present in Billieux's model. ${ }^{87}$ According to this pathway, what leads to problematic smartphone use is the necessity to maintain relationships and obtain reassurance from others.

Lachmann etal., ${ }^{41}$ associated problematic smartphone use with low empathy and low life satisfaction in samples from China and Germany. Those authors concluded that individuals who are more susceptible to stress in social interactions tend to develop more severe problematic smartphone use - this stress in social interactions is also a shared vulnerability factor for drug addiction. Finally, Brand \& Wegmann ${ }^{88}$ described a higher level of social loneliness and lower level of perceived social support in individuals with Internet-communication disorder, a term they coined to describe a diminished control over the use of online communication applications, such as Facebook ${ }^{\circledR}$, WhatsApp ${ }^{\circledR}$ and Twitter $^{\circledR}$. Therefore, impulsivity and low satisfaction with social support may favor reward-seeking behavior through positive and negative reinforcements that encourage the compulsive use of Facebook through the smartphone. Accessibility, portability and social acceptance of smartphone use almost everywhere endorse the unlimited use of Facebook and hamper the implementation of usage control strategies, increasing the chance of SA in vulnerable individuals.

In a systematic review on FA, Ryan et al. identified that escaping from problems/concerns and procrastination may be other motivations for the abuse of Facebook, which would also lead to a ritual of regularly checking the network aiming to cope with negative mood states, and thus triggering a predisposition to develop user dependency. ${ }^{47}$ Sherman et al., in a recent paper, reported that adolescents showed greater activity in brain regions associated with reward processing while viewing pictures that had received a large number of "likes" on Instagram ${ }^{\circledR} .89$ These findings suggest that the reinforcing strategies of Facebook may result in excessive use or abuse. This behavior is problematic when individuals become eager to receive more likes, ignoring negative consequences in daily life, e.g., decreased productivity in the workplace or academia. ${ }^{47}$ Therefore, the use of Facebook through smartphones by vulnerable individuals can become compulsive, paralleling behaviors observed in association with chemical and other behavioral addictions (i.e., gambling, sex).

The concepts of SA and Internet addiction may also be difficult to distinguish, as the main reason for using the smartphone is to access the Internet. However, in 2013, Kwon et al. demonstrated an overlap of approximately $18 \%$ of the variance in both constructs (correlation of $r=0.42) .{ }^{90}$ Moreover, in 2016, Montag et al. demonstrated an overlap of $24 \%$ of the variance in SA and Internet addiction (correlation of $r=0.49$ ). ${ }^{46}$ These data suggest that while smartphone and Internet addiction are related, there are significant differences between both constructs.

Internet addiction and other forms of digital addictions are more prevalent in the male gender, while SA is more frequently observed in females ${ }^{46}$; such differences may be related to the messenger/communication services that are exclusive to smartphones, such as WhatsApp ${ }^{\circledR} .46$ Individuals with Internet addiction are more dependent on electronic games, while smartphone addicts are more addicted to social networks. ${ }^{50,51,91-93}$ Smartphone users can access Internet content virtually anywhere and anytime, which is not possible when other Internetaccessing devices are used. Therefore, the differences between SA and Internet addiction may reflect the specificities of the purpose, content, accessibility and functions of the technological device employed.

Brand's Interaction of Person-Affect-CognitionExecution (I-PACE) model $^{94}$ also seeks to identify characteristics that differentiate between specific types of Internet use disorders and predispose different individuals to become dependent on different types of Internet content (e.g., gaming, gambling, pornography, buying, and social networking). The $\mathrm{P}$ component of the model refers to predisposition variables that lead to different types of Internet addiction, such as genetic profiles, childhood adversities, psychiatric comorbidities and dysfunctional personality traits. The $A$ and $C$ components of the model refer to affective and cognitive responses to external or internal stimuli, such 
as perceived stress resulting from personal conflicts or abnormal mood, and addiction-related cues. Finally, the E component of the model refers to reduced executive functions, low inhibitory control and disadvantageous decision-making related to the use of specific applications/sites, which correlates to neurofunctional alterations in imaging tests. Considering this model, different individual characteristics could predispose to the development of dependence on specific types of Internet content through smartphones.

Regarding the contents accessed through smartphones that can lead to dependence on the device, we can transpose Davis's model ${ }^{95}$ of Internet addiction to SA. The model presents two subtypes of Internet addiction: 1) general internet addiction; and 2) specific internet addiction. There would be a subtype of "general SA," which would reflect an unreasonable and misguided use of the device, as if the user had to "randomly touch the device." The other subtype would be the "specific SA," in which the user would display usage-oriented behavior for specific activities accessed through the smartphone, like games, social networks, videos, and more. Users with general SA would have a dependence on the device itself, while users with specific SA would be dependent on specific activities that could also be performed using other means, such as computers.

Several studies have reported that the type of content most frequently accessed by smartphone dependents is social networks. ${ }^{16,25,37,49-53}$ The association between SA and dependence on social networks can be explained by a few reasons. Smartphones' portability and accessibility favor excessive and quick access to social networks. $16,52,96,97$ As a result, when compared to computer-based social network access, smartphones could be associated with an increased risk for addiction, ${ }^{98,99}$ such as drugs with shorter half-lives and faster peak-plasma concentrations. By analogy with drug addiction, "likes" and comments on social networks may produce the release of phasic dopamine pulses in the nucleus accumbens, generating positive reinforcement of short duration, possibly favoring more frequent use and addictive behavior. ${ }^{98-102}$ This ability of social networks to activate the reward system quickly and frequently may also explain the greater severity of $\mathrm{SA}$ when associated with FA.

Facebook offers the user the possibility to like and receive likes on photos and updates from other users, which is a form of social reinforcement by peers. ${ }^{103}$ Meshi et al. tested this hypothesis in an experimental setting and studied the neural correlation of likes using functional magnetic resonance imaging (MRI). The authors observed an increase in neural activity of the nucleus accumbens caused by positive judgments of the individuals themselves. Also, this increase was greater than that caused by the viewing of positive judgment to others. The authors also reported a positive correlation between excessive Facebook use and the neural effect of social reinforcement on MRI. ${ }^{104}$ The nucleus accumbens is considered the reward center of the brain, ${ }^{104}$ which may lead to the conclusion that Facebook users perceive likes as a reinforcing stimulus. Montag et al. ${ }^{103}$ reported that students who regularly checked Facebook more frequently had lower volumes of nucleus accumbens. Moreover, the reduction of nucleus accumbens volume was less associated with total time of Facebook use than with the amount of regular checking. The authors concluded that frequent Facebook checking through smartphones is a reward-seeking behavior, and that reward-seeking behaviors may be a risk factor for developing dependence on Facebook through the smartphone, considering that the device favors regular checking of social networks.

\section{Conclusions}

In our sample, the co-occurrence of SA and FA correlated with higher levels of negative consequences and lower levels of social support satisfaction. These results strongly suggest that SA and FA share some elements of vulnerability. Further studies are warranted to clarify the directions of the associations identified.

\section{Acknowledgements}

This study received financial support from Fundação de Amparo à Pesquisa do Estado de Minas Gerais (FAPEMIG; grant APQ-02572-16, APQ-04347-17), from Secretaria de Política Sobre Drogas (SENAD/MJ; grant TED 01/2017), and from Conselho Nacional de Desenvolvimento Científico e Tecnológico (CNPq; grant 313944/2018-0).

\section{Disclosure}

Julia Machado Khoury, Maila de Castro Lourenço das Neves, Marco Antônio Valente Roque, André Augusto Correa de Freitas, and Frederico Duarte Garcia have received grants from Janssen; Frederico Duarte Garcia has also received grants from Daiichi-Sankyo. No other conflicts of interest declared concerning the publication of this article. 


\section{References}

1. Choi SW, Kim DJ, Choi JS, Ahn H, Choi EJ, Song WY, et al. Comparison of risk and protective factors associated with smartphone addiction and Internet addiction. J Behav Addict. 2015;4:308-14

2. Oulasvirta A, Rattenbury T, Ma L, Raita EJP. Habits make smartphone use more pervasive. Pers Ubiquit Comput. 2012;16:105-14.

3. Reisinger D. Worldwide smartphone user base hits 1 billion [Internet]. 2014 [cited 2018 Aug 08]. https://www.cnet.com/ news/worldwide-smartphone-user-base-hits-1-billion/

4. Montag C, Błaszkiewicz K, Lachmann B, Sariyska R, Andone I, Trendafilov $B$, et al. Recorded behavior as a valuable resource for diagnostics in mobile phone addiction: evidence from psychoinformatics. Behav Sci (Basel). 2015;5:434-42.

5. Bianchi A, Phillips JG. Psychological predictors of problem mobile phone use. Cyberpsychol Behav. 2005;8:39-51.

6. Zulkefly SN, Baharudin R. Mobile phone use amongst students in a university in Malaysia: its correlates and relationship to psychological health. Eur J Sci Res. 2009;27:206-18.

7. Monk A, Carroll J, Parker S, Blythe M. Why are mobile phones annoying? Behav Inf Technol. 2004;23:33-41.

8. Kubey RW, Lavin MJ, Barrows JR. Internet use and collegiate academic performance decrements: early findings. J Commun. 2001;51:366-82.

9. Pierce TA, Vaca R. Distracted: academic performance differences between teen users and non-users of MySpace and other communication technology. J Syst Cybern Inf. 2008;6:67-71.

10. Srivastava L. Mobile phones and the evolution of social behaviour. Behav Inf Technol. 2005;24:111-29.

11. Duke É, Montag C. Smartphone addiction, daily interruptions and self-reported productivity. Addict Behav Rep. 2017;6:90-5.

12. Abu-Jedy A. Mobile phone addiction and its relationship with selfdiscloser among sample of students from University of Jordan And Amman Al-Ahliyya University. Jordan J Educ Sci. 2008;4:13750.

13. Devís-Devís J, Peiró-Velert C, Beltrán-Carrillo VJ, Tomás JM. Screen media time usage of 12-16 year-old Spanish school adolescents: effects of personal and socioeconomic factors, season and type of day. J Adolesc. 2009;32:213-31.

14. Chóliz M. Mobile-phone addiction in adolescence: the test of mobile phone dependence (TMD). Prog Health Sci. 2012;2:3344.

15. Hong FY, Chiu SI, Huang DH. A model of the relationship between psychological characteristics, mobile phone addiction and use of mobile phones by Taiwanese university female students. Comput Human Behav. 2012;28:2152-9.

16. Lee $\mathrm{H}, \mathrm{Kim}$ JW, Choi TY. Risk factors for smartphone addiction in Korean adolescents: smartphone use patterns. J Korean Med Sci. 2017;32:1674-9.

17. Al-Barashdi HS, Bouazza A, Jabur NH. Smartphone addiction among university undergraduates: a literature review. J Sci Res Rep. 2015;4:210-25.

18. Head M, Ziolkowski N. Understanding student attitudes of mobile phone features: Rethinking adoption through conjoint, cluster and SEM analyses. Comput Human Behav. 2012;28:2331-9.

19. Shambare R, Rugimbana R, Zhowa T. Are mobile phones the 21st century addiction? Afr J Bus Manag. 2012;6:573-7.

20. Castells M, Fernandez-Ardevol M, Qiu JL, Sey A, editors. The mobile communication society: a cross-cultural analysis of available evidence on the social uses of wireless communication technology. International Workshop on Wireless Communication Policies and Prospects: A Global Perspective; 2004 October; Los Angeles, CA, USA.

21. Prezza M, Pacilli MG, Dinelli S. Loneliness and new technologies in a group of Roman adolescents. Comput Human Behav. 2004;20:691-709.

22. Li C, Dang J, Zhang X, Zhang Q, Guo J. Internet addiction among Chinese adolescents: The effect of parental behavior and selfcontrol. Comput Human Behav. 2014;41:1-7.

23. Özdemir $Y$, Kuzucu $Y, A k$ Ş. Depression, loneliness and Internet addiction: how important is low self-control? Comput Human Behav. 2014;34:284-90.

24. James D, Drennan J, editors. Exploring addictive consumption of mobile phone technology. Australian and New Zealand Marketing Academy Conference; 2005 December; Perth, Australia.

25. Choi SW, Kim DJ, Choi JS, Ahn H, Choi EJ, Song WY, et al. Comparison of risk and protective factors associated with smartphone addiction and Internet addiction. J Behav Addict. 2015;4:308-14.

26. Kim SM, Huh $\mathrm{HJ}$, Cho $\mathrm{H}$, Kwon $\mathrm{M}$, Choi JH, Ahn $\mathrm{HJ}$, et al. The effect of depression, impulsivity, and resilience on smartphone addiction in university students. J Korean Neuropsychiatr Assoc. 2014;53:214-20.

27. Lachmann B, Duke É, Sariyska R, Montag C. Who's addicted to the Smartphone and/or the Internet? Psychol Pop Media Cult. 2017;8:182-9.

28. Montag C, Błaszkiewicz K, Sariyska R, Lachmann B, Andone I, Trendafilov B, et al. Smartphone usage in the 21st century: who is active on WhatsApp? BMC Res Notes. 2015;8:331.

29. Javid M, Malik MA, Gujjar AA. Mobile phone culture and its psychological impacts on students' learning at the university level. Lang India. 2011;11:415-22.

30. Shaffer $\mathrm{HJ}$. Understanding the means and objects of addiction: technology, the Internet, and gambling. J Gambl Stud. $1996 ; 12: 461-9$.

31. Griffiths M. Internet addiction: fact or fiction? Psychologist. 1999; 5:246-50.

32. Thomée S, Härenstam A, Hagberg M. Mobile phone use and stress, sleep disturbances, and symptoms of depression among young adults - a prospective cohort study. BMC Public Health. $2011 ; 11: 66$

33. Walsh SP, White KM, Young RM. Over-connected? A qualitative exploration of the relationship between Australian youth and their mobile phones. J Adolesc. 2008;31:77-92.

34. Babadi-Akashe Z, Zamani BE, Abedini Y, Akbari $H$, Hedayati N. The relationship between mental health and addiction to mobile phones among university students of Shahrekord, Iran. Addict Health. 2014;6:93-9.

35. Demirci K, Akgönül M, Akpinar A. Relationship of smartphone use severity with sleep quality, depression, and anxiety in university students. J Behav Addict. 2015;4:85-92.

36. Kuss DJ, Lopez-Fernandez O. Internet addiction and problematic Internet use: A systematic review of clinical research. World J Psychiatry. 2016;6:143-76.

37. Milošević-Đorđević JS, Žeželj IL. Psychological predictors of addictive social networking sites use: the case of Serbia. Comput Human Behav. 2014;32:229-34.

38. American Psychiatric Association. Diagnostic and Statistical Manual of Mental Disorders, 5th Edition (DSM-5). Washington: APA; 2013.

39. American Psychiatric Association. Manual diagnóstico e estatístico de transtornos mentais: texto revisado (DSM-IV-TR). Porto Alegre: Artmed; 2002.

40. World Health Organization. The ICD-10 classification of mental and behavioural disorders: diagnostic criteria for research. Geneva: World Health Organization; 1993.

41. Lachmann B, Sindermann C, Sariyska RY, Luo R, Melchers MC, Becker $B$, et al. The role of empathy and life satisfaction in Internet and smartphone use disorder. Front Psychol. 2018;9:398.

42. Soror AA, Hammer BI, Steelman ZR, Davis FD, Limayem MM. Good habits gone bad: explaining negative consequences associated with the use of mobile phones from a dual $\square$ systems perspective. Inf Syst J. 2015;25:403-27.

43. Sha $P$, Sariyska $R$, Riedl $R$, Lachmann B, Montag CJ. Linking Internet communication and smartphone use disorder by taking a closer look at the Facebook and WhatsApp applications. Addict Behav Rep. 2018;9:100148.

44. Billieux J, Maurage P, Lopez-Fernandez O, Kuss DJ, Griffiths MD. Can disordered mobile phone use be considered a behavioral addiction? An update on current evidence and a comprehensive model for future research. Curr Addict Rep. 2015:2:156-62.

45. Elhai JD, Dvorak RD, Levine JC, Hall BJ. Problematic smartphone use: a conceptual overview and systematic review of relations with anxiety and depression psychopathology. J Affect Disord. 2017;207:251-9.

46. Duke É, Montag C. Smartphone addiction and beyond: initial insights on an emerging research topic and its relationship to Internet addiction. In: Montag $\mathrm{C}$, Reuter $\mathrm{M}$, editors. Internet addiction. Vienna: Springer; 2017. p. 359-72.

47. Ryan T, Chester A, Reece J, Xenos S. The uses and abuses of Facebook: a review of Facebook addiction. J Behav Addict. 2014;3:133-48.

48. Roberts J, Yaya L, Manolis C. The invisible addiction: cell phone activities and addiction among male and female college students. J Behav Addict. 2014;3:254-65. 
49. Igarashi T, Motoyoshi T, Takai J, Yoshida T. No mobile, no life: selfperception and text-message dependency among Japanese high school students. Comput Human Behav. 2004;24:2311-24.

50. Weiser EB. Gender differences in Internet use patterns and Internet application preferences: a two-sample comparison. Cyberpsychol Behav. 2000;3:167-78.

51. Heo J, Oh J, Subramanian S, Kim Y, Kawachi I. Addictive internet use among Korean adolescents: a national survey. PLoS One. 2014;9:e87819.

52. Jeong $\mathrm{SH}$, Kim H, Yum JY, Hwang Y. What type of content are smartphone users addicted to?: SNS vs. games. Comput Human Behav. 2016;54:10-7.

53. Kneer J, Glock S. Escaping in digital games: the relationship between playing motives and addictive tendencies in males. Comput Human Behav. 2013;29:1415-20.

54. Spekman ML, Konijn EA, Roelofsma PH, Griffiths MD. Gaming addiction, definition and measurement: a large-scale empirical study. Comput Human Behav. 2013;29:2150-5.

55. Kardefelt-Winther D. Problematizing excessive online gaming and its psychological predictors. Comput Human Behav. 2014;31:11822.

56. Khumsri J, Yingyeun R, Mereerat M, Hanprathet N, Phanasathit M. Prevalence of Facebook addiction and related factors among Thai high school students. J Med Assoc Thai. 2015;98 Suppl 3:S5160 .

57. Hormes JM, Kearns B, Timko CA. Craving Facebook? Behavioral addiction to online social networking and its association with emotion regulation deficits. Addiction. 2014;109:2079-88.

58. Błachnio A, Przepiorka A, Pantic I. Association between Facebook addiction, self-esteem and life satisfaction: a cross-sectional study. Comput Human Behav. 2016;55:701-5.

59. Leung L. Leisure boredom, sensation seeking, self-esteem, addiction symptoms and patterns of cell phone use. In: Konijn EA, Tanis MA, Utz S, Linden A, editors. Mediated interpersonal communication. Mahwah: Lawrence Erlbaum Associates; 2007. p. 359-81.

60. Leung L. Linking psychological attributes to addiction and improper use of the mobile phone among adolescents in Hong Kong. J Child Media. 2008;2:93-113.

61. Protégeles. Seguridad infantil y costumbres de los menores en la telefonia móvil. Madrid: Defensor del Menor en la Comunidad de Madrid; 2005.

62. Institudo de Pesquisa Econômica Aplicada. A mobilidade urbana no Brasil [Internet]. 2011 [cited 2018 Aug 08]. http://www. ipea.gov.br/portal/images/stories/PDFs/comunicado/110525_ comunicadoipea94.pdf

63. Sánchez-Martínez M, Otero A. Factors associated with cell phone use in adolescents in the community of Madrid (Spain). Cyberpsychol Behav. 2009;12:131-7.

64. Halayem S, Nouira O, Bourgou S, Bouden A, Othman S, Halayem M. Le téléphone portable: une nouvelle addiction chez les adolescents. Tunis Med. 2010;88:593-6.

65. Martinotti G, Villella C, Di Thiene D, Di Nicola M, Bria P, Conte $\mathrm{G}$, et al. Problematic mobile phone use in adolescence: a crosssectional study. J Public Health. 2011;19:545-51.

66. Smetaniuk P. A preliminary investigation into the prevalence and prediction of problematic cell phone use. J Behav Addict. 2014;3:41-53.

67. Davey S, Davey A. Assessment of smartphone addiction in Indian adolescents: a mixed method study by systematic-review and meta-analysis approach. Int J Prev Med. 2014;5:1500-11.

68. Khoury JM, de Freitas AAC, Roque MAV, Albuquerque MR, das Neves MCL, Garcia FD. Assessment of the accuracy of a new tool for the screening of smartphone addiction. PLoS One. 2017; 12:e0176924.

69. Silva HRS, Areco KCN, Bandeira-Paiva P, Galvão PVM, García AM, Silveira DX. Semantic equivalence and confiability of the Portuguese version of the Bergen Facebook Addiction Scale. J Bras Psiquiatr. 2015;64:17-23.

70. Andreassen CS, Torsheim T, Brunborg GS, Pallesen S. Development of a Facebook addiction scale. Psychol Rep. 2012;110:501-17.

71. Sheehan DV, Lecrubier $Y$, Sheehan KH, Amorim P, Janavs J, Weiller $\mathrm{E}$, et al. The Mini-International Neuropsychiatric Interview (MINI): the development and validation of a structured diagnostic psychiatric interview for DSM-IV and ICD-10. J Clin Psychiatry. 1998; 59 Suppl 20:22-33; quiz 34-57.

72. Amorim P. Mini International Neuropsychiatric Interview (MINI): validação de entrevista breve para diagnóstico de transtornos mentais. Rev Bras Psiquiatr. 2000;22:106-15.
73. Ribeiro JLP. Escala de satisfação com o suporte social (ESSS). Aná Psicológica 1999;17:547-58.

74. Malloy-Diniz LF, Paula JJ, Vasconcelos AG, Almondes KM, Pessoa $R$, Faria $L$, et al. Normative data of the Barratt Impulsiveness Scale 11 (BIS-11) for Brazilian adults. Rev Bras Psiquiatr. 2015;37:245-8.

75. Gomes ÁKV, Diniz LFM, Lage GM, de Miranda DM, de Paula JJ, Costa $D$, et al. Translation, adaptation, and validation of the Brazilian version of the Dickman impulsivity inventory (Br-DII). Front Psychol. 2017;8:1992.

76. Zuckerman M, Kolin EA, Price L, Zoob I. Development of a sensation-seeking scale. J Consult Psychol. 1964;28:477.

77. Ferreira JFKS. Busca de sensações e dependência alcoólica: um estudo com doentes alcoólicos [master's thesis]. Porto: Universidade do Porto; 2009.

78. Hoyle RH, Stephenson MT, Palmgreen $\mathrm{P}$, Lorch EP, Donohew RL. Reliability and validity of a brief measure of sensation seeking. Pers Indid Differ. 2002;32:401-14.

79. Jenaro C, Flores N, Gómez-Vela M, González-Gil F, Caballo C. Problematic internet and cell phone use: psychological, behavioral, and health correlates. Addict Res Theory. 2007;15:309-20.

80. Kawasaki N, Tanei S, Ogata F, Burapadaja S, Loetkham C, Nakamura $T$, et al. Survey on cellular phone usage on students in Thailand. J Physiol Anthropol. 2006;25:377-82.

81. Chung N. Korean adolescent girls' addictive use of mobile phones to maintain interpersonal solidarity. Soc Behav Pers. 2011;39:1349-58.

82. Hakoama M, Hakoyama S. The impact of cell phone use on social networking and development among college students. AABSS J. 2011;15:1-20.

83. Perry SD, Lee KC. Mobile phone text messaging overuse among developing world university students. Communicatio. 2007;33:6379.

84. Bianchi A, Phillips JG. Psychological predictors of problem mobile phone use. Cyberpsychol Behav. 2005;8:39-51.

85. Demirci K, Akgönül M, Akpinar A. Relationship of smartphone use severity with sleep quality, depression, and anxiety in university students. J Behav Addict. 2015;4:85-92.

86. Jenaro C, Flores N, Gómez-Vela M, González-Gil F, Caballo C. Problematic Internet and cell phone use: Psychological, behavioral, and health correlates. Addict Res Theory. 2007;15:309-20.

87. Billieux J, Schimmenti A, Khazaal Y, Maurage P, Heeren A. Are we overpathologizing everyday life? A tenable blueprint for behavioral addiction research. J Behav Addict. 2015;4:119-23.

88. Wegmann $E$, Brand $M$. Internet-communication disorder: It's a matter of social aspects, coping, and Internet-use expectancies. Front Psychol. 2016; 7:1747.

89. Sherman LE, Payton AA, Hernandez LM, Greenfield PM, Dapretto $M$. The power of the like in adolescence: effects of peer influence on neural and behavioral responses to social media. Psychol Sci. 2016;27:1027-35.

90. Kwon M, Lee JY, Won WY, Park JW, Min JA, Hahn C, et al. Development and validation of a smartphone addiction scale (SAS). PLoS One. 2013;8:e56936.

91. Cooper A, Morahan-Martin J, Mathy RM, Maheu M. Toward an increased understanding of user demographics in online sexual activities. J Sex Marital Ther. 2002;28:105-29.

92. Fattore $L$, Melis $M$, Fadda $P$, Fratta W. Sex differences in addictive disorders. Front Neuroendocrinol. 2014;35:272-84.

93. Johansson A, Götestam KG. Internet addiction: characteristics of a questionnaire and prevalence in Norwegian youth (12-18 years). Scand J Psychol. 2004;45:223-9.

94. Brand M, Young KS, Laier C, Wölfling K, Potenza MN. Integrating psychological and neurobiological considerations regarding the development and maintenance of specific Internet-use disorders: an Interaction of Person-Affect-Cognition-Execution (I-PACE) model. Neurosci Biobehav Rev. 2016;71:252-66.

95. Davis RA. A cognitive-behavioral model of pathological Internet use. Comput Human Behav. 2001;17:187-95.

96. Granda P, Jimena L. ¿Se constituye el uso del Smartphone en una adicción? Medellín: Universidad de San Buenaventura Seccional Medellín; 2013.

97. Chóliz M. Mobile phone addiction: a point of issue. Addiction. 2010;105:373-4.

98. Koob GF, Volkow ND. Neurobiology of addiction: a neurocircuitry analysis. Lancet Psychiatry. 2016;3:760-73.

99. Holly EN, Boyson CO, Montagud-Romero S, Stein DJ, Gobrogge $\mathrm{KL}$, DeBold JF, et al. Episodic social stress-escalated cocaine selfadministration: role of phasic and tonic corticotropin releasing 
factor in the anterior and posterior ventral tegmental area. J Neurosci. 2016;36:4093-105.

100.Saddoris MP, Wang X, Sugam JA, Carelli RM. Cocaine selfadministration experience induces pathological phasic accumbens dopamine signals and abnormal incentive behaviors in drugabstinent rats. J Neurosci. 2016;36:235-50.

101.Pascoli V, Terrier J, Hiver A, Lüscher C. Sufficiency of mesolimbic dopamine neuron stimulation for the progression to addiction. Neuron. 2015;88:1054-66.

102. Montag C, Zhao Z, Sindermann C, Xu L, Fu M, Li J, et al. Internet communication disorder and the structure of the human brain: initial insights on WeChat addiction. Sci Rep. 2018;8:2155.

103. Montag C, Markowetz A, Blaszkiewicz K, Andone I, Lachmann B, Sariyska R, et al. Facebook usage on smartphones and gray matter volume of the nucleus accumbens. Behav Brain Res. 2017:329:221-8.

104. Meshi D, Morawetz C, Heekeren HR. Nucleus accumbens response to gains in reputation for the self relative to gains for others predicts social media use. Front Hum Neurosci. 2013;7:439.

\section{Correspondence:}

Frederico Duarte Garcia

Av. Alfredo Balena, 190

30130-100 - Belo Horizonte, MG -Brazil

Tel.: +55 (31) 34099786

E-mail: frederico.garciad@gmail.com 